\title{
Study on the Influencing Factors of Innovation and Entrepreneurship Education in Colleges and Universities and Its Countermeasures*
}

\author{
Yun Cai \\ Shandong Yingcai University \\ Jinan, China 250104
}

\begin{abstract}
Recently, the state has introduced a series of policies to encourage innovation and entrepreneurship in colleges and universities, and many colleges and universities have made active exploration and accumulated some valuable experiences, but there still are some problems which, to some extent, are restricting rapid and healthy development of colleges and universities. The influencing factors include the colleges and universities' degree of emphasis, teaching faculty, second classroom, etc. Therefore, to promote the continuous development of innovation and entrepreneurship education in colleges and universities, it has to start from the curriculum system, teaching faculty, practical activities, school-enterprise cooperation, etc
\end{abstract}

Keywords-innovation and entrepreneurship education; influencing factor; strategy

\section{INTRODUCTION}

With the increase of population, the number of jobs is gradually decreasing and the pressure of employment is continuously increasing. Colleges and universities that only focus on developing talents before are finding an outlet for their students. As a result, the society began to pay attention to the question: whether the knowledge students learn from the school can still keep pace with the era of knowledge economy? What he has learned has nothing to do with the job he takes and what he has applied are not what he has learned have become common phenomena. The development and progress of the age are calling for the reform of education purpose, together with the goal and mode of talent training.

\section{OVERVIEW OF INNOVATION AND ENTREPRENEURSHIP EDUCATION}

General Office of the State Council issued the Opinions for the Implementation of Deepening Education Reform on Innovation and Entrepreneurship in Universities and Colleges

*Project: This paper is the research achievement of Shandong Provincial social science planning project "Study on Innovation and Entrepreneurship Education Mode in Colleges and Universities Based on Multiple Collaboration of 'Government, Enterprises, Universities and Research Institutions"” in 2018 (project number: 18CJYJ30) and Shandong Yingcai College school-level major scientific research project "Research on Characteristics of and Guidance on College Students' Career Value Orientation" (project number: 17YCZDRW05).
(G.F. [2015] No. 36) which clearly requires universities and colleges to "perform the responsibilities of innovation and entrepreneurship education". [1] Colleges and universities shall make a deep understanding and take active actions with high subjective consciousness to shoulder the great mission given by the times. Although China has made some progress in the implementation and exploration of innovation and entrepreneurship education in universities and colleges in recent years, the innovation and entrepreneurship education in universities and colleges in China is still in the stage of "having resonance, without actions", "more extracurricular activities, less policies for encouragement", "more elective courses, less compulsory courses", "more non-professional teachers, less senior teachers", "more entrepreneurship materials, less evaluation", and "more classroom teaching, less practical exercises". There is a big gap in domestic and overseas innovation and entrepreneurship education, and domestic innovation and entrepreneurship education cannot meet the meet the needs of the society and students. According a survey conducted by Tsinghua University Innovation and Entrepreneurship Research Center, it is found that the average level of innovation and entrepreneurship education in China lag far behind the corresponding global average level found by Global Entrepreneurship Monitor (GEM) through investigation Thereinto, apart from "financial matters", "practical experience", "the government's support", etc. are also the influencing factors on student entrepreneurship. Influenced by outdated ideas, innovation and entrepreneurship education system, etc., China's innovation and entrepreneurship education faces many problems, so it is an urgent problem about how to achieve success in innovation and entrepreneurship education.

\section{FACTORS INFLUENCING THE DEVELOPMENT OF INNOVATION AND ENTREPRENEURSHIP EDUCATION IN COLLEGES AND UNIVERSITIES}

\section{A. Not Paying Enough Attention to Innovation and Entrepreneurship Education}

In some Chinese colleges and universities, teachers and students have a shallow understanding or even a distorted view of innovation and entrepreneurship education. Some of them hold that innovation and entrepreneurship education is to develop students' ability in creating businesses, while the 
others think that as long as it is not difficult or easy for students to find a job after graduation, it is not necessary to set up innovation and entrepreneurship education, and setting up innovation and entrepreneurship education is only a way to increase employment choices for students after graduation, and so on. It is these misunderstanding and distortion of innovation and entrepreneurship education that cause some universities and colleges to wrongly position them, thus influencing the development of China's innovation and entrepreneurship education.

\section{B. Shortage of Teaching Faculty in Innovation and Entrepreneurship Education}

Most teachers in innovation and entrepreneurship education in colleges and universities of China mainly engage in employment guiding and just concurrently serve in innovation and entrepreneurship education, and most of them have no or barely have experience in innovation and entrepreneurship, but those who serve as student entrepreneurship instructors are required to have entrepreneurial experience to some degree so as to properly combining the book knowledge and practice. Therefore, such teaching faculty cannot help students make a real understanding of the concept of entrepreneurship, nor can they give constructive suggestions to students who encounter bottleneck, let alone let students experience the hardship thereof. In this aspect, we should learn from America that teachers in innovation and entrepreneurship education should not only include part-time professional teachers, but also involve entrepreneurs of small or micro businesses, entrepreneurial risk analysts, experts from the government's sociology department, etc.

\section{Less Second Classroom in Innovation and Entrepreneurship Education}

At present, entrepreneurial activities in most colleges and universities are held either to actively encourage students' entrepreneurship or just to publicize the entrepreneurship, and few schools are actually supporting students' entrepreneurship with practical actions. Most colleges and universities promote students' awareness of entrepreneurship by providing them with lectures or by other means, but only few of them integrate entrepreneurship education into the education system so that it is no longer an independent discipline. As a result, entrepreneurship education has not played a positive role among the students. Moreover, students prefer the second classroom. Most students hope that the innovation and entrepreneurship education in their majors centers on the second classroom, combining with theory courses. Besides, operating skills and intelligence required in the process of entrepreneurship can only obtained through practices, it is impossible for students to use only knowledge obtained from theory courses to solve all problems encountered in the process of innovation and entrepreneurship, so the second classroom is more important than the first classroom in the innovation and entrepreneurship education.

\section{IMPROVEMENT MEASURES FOR INNOVATION AND ENTREPRENEURSHIP EDUCATION IN COLLEGES AND UNIVERSITIES}

\section{A. Establish a Mature Curriculum System for Innovation and Entrepreneurship Education}

As innovation and entrepreneurship education involves miscellaneous and complicated contents, it is also complicated to design its curriculum system, which requires starting from the perspective of cross-disciplinary. During the design of the curriculum system for innovation and entrepreneurship education of colleges and universities, the first thing to consider is about how to integrate the innovation and entrepreneurship education with the major education system so that they are not independent from each other, and in this way, entrepreneurship education can become the expansion and development of the quality-oriented education; in specific implementation procedures, it also requires to pay attention to the interdisciplinary coverage and the characteristics of course teaching, so as to strengthen the organic linking of the first classroom and the second classroom to construct an innovation and entrepreneurship education curriculum system centering on the second classroom, combining with the first classroom and having various forms; gradually, the gist of the curriculum system of innovation and entrepreneurship education can be summarized so that teachers can give lessons based on more standardized curriculum instead of arbitrary one. As innovation and entrepreneurship involves a process based on practice, we can set and design relevant required courses of practice simulation.

\section{B. Build High-quality Teaching Faculty in Innovation and Entrepreneurship Education}

One of the most important points in innovation and entrepreneurship education is teaching faculty. According to the characteristics of innovation and entrepreneurship education, those who want to be teachers in innovation and entrepreneurship education are required to have book knowledge of innovation and entrepreneurship as well as the corresponding practical operation experience. In China, most teachers in innovation and entrepreneurship education in colleges and universities are the professional teachers in other majors, of which most are employment advisers. However, these teachers' theoretical knowledge and practical experience in innovation and entrepreneurship education are far from the standard of professional advisers in innovation and entrepreneurship education. In the case of extreme lack of advisers in innovation and entrepreneurship education, the leaders in colleges and universities set lower requirements for these advisers, and also fail to greatly support and encourage these advisers to study and research the education system relating the innovation and entrepreneurship education, which is also a cause of slow development of China's innovation and entrepreneurship education. Incentive measures of colleges and universities are not in place, and there is no doubt that the professional teachers concurrently as teachers in innovation and entrepreneurship education are more willing to contribute more to their own fields, and are not likely to spend more time in innovation and entrepreneurship education. As a result, these teachers have less enthusiasm for innovation and 
entrepreneurship education. [2] In this aspect, we have to learn from America.

It should pay attention to innovation and entrepreneurship. According to the successful experiences of American colleges and universities, to establish teaching faculty required by and matching with entrepreneurship education in colleges and universities, the colleges and universities should adopt a "twopronged approach", that is, training teachers in relevant theoretical knowledge and practice of innovation and entrepreneurship education to make them more professional while actively introducing experienced or famous foreign entrepreneurs as the teaching faculty in innovation and entrepreneurship education. Parallel implementation of training and introduction. On the one hand, make the teachers in innovation and entrepreneurship education become more professional; moreover, through communication with other teachers to brainstorm ideas, make the ideology in innovation and entrepreneurship education become more mature, and help teachers in innovation and entrepreneurship education make a real understanding of what is innovation and entrepreneurship education so that they will no longer apply the traditional teacher-guided teaching method in classroom, but become a guide for students so as to give full play to their guiding functions as teachers. As each individual varies from one to another, teachers should adopt individualized teaching method, that is, according to different individuals, to adopt different teaching methods, such as situational method, experimental method and elicitation method of teaching, so as to guide and stimulate their consciousness of innovation and entrepreneurial ability, helping them become real entrepreneurs. In the same time, during the process of guiding students, the teachers are expected to become professionals with both theoretical knowledge and practical experience in innovation and entrepreneurship education. [3] In the meantime, teachers who have professional knowledge in innovation and entrepreneurship and can give students guidance in innovation and entrepreneurship will have special discernment of social demands for innovation and entrepreneurship education, as well as development vision and change of innovation and entrepreneurship. On the other hand, by utilizing the existing society resources, actively introduce social talents and expand the teaching faculty in innovation and entrepreneurship education. Although inviting experienced or famous entrepreneurs to serve as part-time teachers to give students more professional help in entrepreneurship and also to improve the professional level of the teachers in innovation and entrepreneurship education of the school, it is a severe problem about how to introduce them to the school. Teachers should actively carry out in-depth research on innovation and entrepreneurship education, develop relevant curriculum system and improve teaching methods so as to integrate innovation and entrepreneurship education with professional education to make the both infiltrate each other. In addition, the school should consider giving some policy support and reward to improve teachers' enthusiasm for innovation and entrepreneurship education and encourage them to make indepth research, so as to drive forward the development of innovation and entrepreneurship education, and make the teachers in innovation and entrepreneurship education become high-quality ones with both theoretical knowledge and skill experiences.

\section{Carry out Innovation and Entrepreneurship Education Practice Activities}

Integrate different resources and combine them with the specialties set by the school to build a business internship platform activity that links campuses with companies. Let students make rational use of their resources, actively participate in practice, and contribute to social and economic development. They also become teachers' teaching practice platforms. It is possible to try universities and colleges to construct such activity conditions with enterprises, provide students with innovation and entrepreneurship programs, and further study in the internship. Before starting a business, college students enter the enterprises to understand the basic operation process of the enterprises, and can also intuitively understand and feel the entrepreneurial ability and entrepreneurial spirit of entrepreneurs. In addition, except for practice platform, it also needs a scientific and improved operation mechanism to ensure the standardized operation of the platform. In terms of different practice platforms, the operation mechanism should have different characteristics because of their difference in objectives. During the practice, the duties of colleges and universities are exploring the range that can be applicable to explore various innovations and entrepreneurship, the main conditions of operation and corresponding strategies for supporting system construction. [4]These include institutions and procedures for implementing innovative entrepreneurial activities, planning institutions and systems for operational innovation and entrepreneurship practice, institutional inspection criteria and evaluation system and so on. The above content contributes to the extension, rapid development and growth of its position in the innovation and entrepreneurship education practice platform, which is also a convenient channel for further innovation and entrepreneurship education in colleges and universities.

\section{Actively Interact with Enterprises and Establish a Good Support Bond}

The advancement of innovation and entrepreneurship education is not just unilateral in the school, but also needs the support of the enterprises and the country. Colleges and universities give students development in theory and skills and encouragement in financial resources; the country gives students encouragement by issuing a serious of policy documents; the encouragement of human and financial resources of major enterprises in society is necessary for the development of innovation and entrepreneurship education. It is a project that needs multi-cooperation support and requires collaboration from all walks of life. Therefore, if you want to innovate in the development of entrepreneurship education, building a "trinity" model of colleges and universities, enterprises, and countries will promote and support each other. The rational integration of resources of all parties is necessary. Innovation and entrepreneurship education need to organically integrate the first classroom with the second classroom. The most important feature is the operability of the second classroom. Innovative thinking, entrepreneurial spirit, and entrepreneurial awareness are gradually formed and 
accumulated in the course of practice in order to serve the future of innovation and entrepreneurship. Therefore, the innovation and entrepreneurship education should take the second class as the main course content. At the same time, many practical activities such as innovation and entrepreneurship competitions, enterprise internships, scientific research and etc. to enhance the effectiveness of innovation and entrepreneurship education. The implementation of undergraduates innovation and entrepreneurship education needs the support and entry of enterprises. In the United States, enterprises will provide students with the support of human resources, material resources and financial resources for the innovation and entrepreneurship education of students, and provide students with practical platforms and opportunities. And the major enterprises support students by establishing a joint innovation and entrepreneurship education research center with students. It is in this atmosphere of mutual support that the brand that has emerged has also contributed to the economic development of the United States. It can be seen that in the innovation and entrepreneurship education, good synergy and cooperation between the parties will certainly bring about a good harvest.

\section{CONCLUSION}

Compared with universities in the United States, the innovation and entrepreneurship education in Chinese universities is not rich in teaching methods, and there are few problems in the related series of courses. The concept of educating people, teaching activities and materials used in teaching are also important in the innovation and entrepreneurship education curriculum system. We can refer to the successful experience of the United States and find a new path for innovation and entrepreneurship education that combines industry and education, build a platform for innovation and entrepreneurship for students, organize "trinity" good linkage mechanism of colleges and universities, government and enterprises, and actively create innovation and entrepreneurship education activity base and innovation and entrepreneurship incubation base. Students will gain practical experience and entrepreneurial experience through personal internships in various enterprises, and through the communication with successful people in the enterprises, students' vision is opened, their mind is broadened and their desire for innovation and entrepreneurship is further enhanced. The innovation and entrepreneurship base can provide funds, entrepreneurial consulting and entrepreneurial services so that students' desire for innovation and entrepreneurship can be realized.

\section{REFERENCES}

[1] General Office of the State Council. Implementing Opinions of General Office of the State Council on Deepening Reforms in Innovation and Entrepreneurship Education in Institutions of Higher Learning [EB/OL].http://www.gov.cn/zhengce/content/2015-

05/13/content_9740.htm, 2015-05-13. 国务院办公厅.国务院办公厅关 于深化高等学校创新创业教育改革的实施意 [EB/OL].http://www.gov.cn/zhengce/content/201505/13/content_9740.htm,2015-05-13.

[2] Li Jiahua, Lu Xudong. Integrating innovation and entrepreneurship education into college and university talents training system [J]. Higher education in China, 2010 (12): 9-11. 李家华, 卢旭东.把创新创业教 育融入高校人才培养体系 [J].中国高等教育, 2010(12): 9-11。

[3] Shi Minfeng. The enlightenment of "American model" to the construction of education model of Chinese characteristics [J]. Adult Education, 2008 (1): 91-92. 施敏峰.“美国模式”对构建中国特色创业 教育模式的启示[J].成人教育, 2008(11): 91-92.

[4] Liu Wei. Reflections on the construction of education talent training system for innovation and entrepreneurship in colleges and universities [J]. Science of Education, 2011 (5): 64-67. 刘伟. 高校创新创业教育人 才培养体系构建的思考 [J].教育科学, 2011（5）：64-67. 